\author{
Asian Journal of \\ Medical and Biological Research \\ ISSN 2411-4472 (Print) 2412-5571 (Online) \\ www.ebupress.com/journal/ajmbr
}

\title{
Article \\ Production performance of lettuce (Lactuca sativa): aquaponics versus traditional soil
}

K. M. Shakil Rana*, Mymona Jahan, Zannatul Ferdous and M. A. Salam

Department of Aquaculture, Bangladesh Agricultural University, Mymensingh-2202, Bangladesh

*Corresponding author: K. M. Shakil Rana, Department of Aquaculture, Bangladesh Agricultural University, Mymensingh-2202. Phone: +8801728300299; E-mail: ranakms@bau.edu.bd

Received: 28 May 2018/Accepted: 20 June 2018/ Published: 30 June 2018

\begin{abstract}
Feeding the ever increasing population in a safe way has become a rising challenge because of reckless use of natural resources. Substitution of traditional farming system with cost effective integration of different production units has emerged as potential solution. In this regards, aquaponics has already put back the traditional farming systems in facing the burning issues of food safety. The experiment was designed to make a comparison of lettuce (Lactuca sativa) production between aquaponics $\left(\mathrm{T}_{1}\right)$ and traditional soil growbeds $\left(\mathrm{T}_{2}\right)$ in laboratory condition at the Aquaponics Laboratory, Bangladesh Agricultural University (BAU), Mymensingh. Each of the treatment has three replications that were placed randomly. A Seven hundred fifty liter water tank was set for fish rearing where 50 tilapia (Oreochromis niloticus) and 20 magur (Clarias batrachus) fry were released. Tilapia was fed with commercial floating feed while magur with sinking feed. Six $(44 \times 26 \times 24 \mathrm{~cm} 3)$ containers, three for each treatment, were used for lettuce sapling plantation. The fish waste water was irrigated into aquaponics beds and then returned to the fish tank as the thumb role of aquaponics. Fish, plants, water and soil quality parameters were sampled fortnightly, analyzed chemically in the aquaponic laboratory. The results revealed that the performance of $T_{2}$ was better than the $T_{1}$ in terms of lettuce growth in respect of plant height, leaf number, plant and root weight. Lettuce production was comparatively higher in $\mathrm{T}_{2}$ (123.25 tons/ha/89 days), than $\mathrm{T}_{1}$ (107.89 tons/ha/89 days). This might be attributed to the higher nutrient content of the traditional soil $\left(\mathrm{T}_{2}\right)$. At The end of the experiment, the survival rates were 96 and $80 \%$ for tilapia and magur respectively whereas the total productions were 47.33 and 4.19 tons/ha/105days respectively. Further research needed to ascertain the superiority of these systems in food production.
\end{abstract}

Keywords: aquaponics; traditional soil; comparison; lettuce production

\section{Introduction}

Aquaponics is the integration of recirculatory aquaculture system (RAS) and hydropnics in soilless media utilizing beneficial bacteria for hazard free fish and vegetables production (Normala et al., 2010). This integration involves vegetable production without the conventional soil growbed, stripping toxic metabolites from the recirculating fish waste water as plant fertilizer and providing safe water in return for the fish to live in (Waten and Busch, 1984). In the course of aquaculture intervention, considerable amount of fish wastes are produced in the form of unused feed and excreta that ultimately results in ammonia rich toxic water (Harmon, 2001). For the wellbeing of the fish, this waste water is recirculated through hydroponically (soil free) grown plants' growbed where the residing autotrophic nitrifying bacteria (primarily Nitrosomonas and Nitribacter) oxidize ammonia into plant usable nitrates (Tyson et al., 2004; Haug and McCarty, 1972). Thus the system render detoxified safe water to fish, lessen aquaculture water use through recirculation, minimize additional fertilizer and pesticide cost for plant production and produce healthy profitable two or more cash crops (Rakocy, 1997; Timmons et al., 2002). Indeed, the ever increasing population pressure and resulting scarcity of agricultural land, enormous water use for aquaculture production, adulterated food sources for public health and 
the overall climate change issues have brought the aquaponics under the limelight (Salam et al., 2014a; McMurtry et al., 1997). However, several studies have been conducted to justify the potentialities of aquaponics for healthy food production. In some cases, aquaponics has performed better than the conventional methods by creating ideal environment for fish and vegetable production (Geoff, 2002). A number of leafy vegetables have been tested in aquaponic system, among which lettuce Lactuca sativa (Green Oak variety) is a common one because of its wide consumer acceptance. Efficacy of aquaponics over soil or traditional culture method has been under interest of the researchers for decades. Contrary, in Bangladesh, such investigation has not widely been undertaken. Therefore, the present study was conducted with a view to comparing the production performance of lettuce grown in aquaponics and soil (traditional method). The nutrient-flow technique (NFT) was employed to run the aquaponics because of its specific advantages in plant production (Tyson et al., 2001). For fish culture in aquaponics tilapia (Oreochromis niloticus) and magur (Clarias batrachus) were selected for their suitability in captive culture (Bethe et al., 2017; Tanusri, 2013; Islam et al., 2018).

\section{Materials and Methods \\ 2.1. Experimental design}

The experiment was carried out for 89 days from 10 December, 2014 to 8 March, 2015 at the aquaponics laboratory, Faculty of Fisheries, Bangladesh Agricultural University, Mymensingh, Bangladesh. Among different types of aquaponic system, media based (NFT) aquaponics was chosen to conduct the present experiment. The design of the study comprised of a fish holding tank $(750 \mathrm{~L})$ and six food grade plastic containers $\left(44 \times 26 \times 24 \mathrm{~cm}^{3}\right)$ to hold the media (substrate/grow bed). Two types of substrates were used in this experiment namely $100 \%$ brick lets and soil separately to assess their performance in terms of lettuce production. Replications of brick lets substrate were indicated as $T_{1} R_{1}, T_{1} R_{2}$ and $T_{1} R_{3}$ whereas $T_{2} R_{1}, T_{2} R_{2}$ and $T_{2} R_{3}$ were used for soil substrate. Two 10 watt air pumps were used for aerating the fish tank. The waste water from the fish tank was irrigated to the grow bed by a 12 watt submersible water pump. A PVC pipe was connected to each container with another plastic pipe to the outlet pipe for draining the water into the fish tank. Inlet and outlet pipes were set to the tank to facilitate water re-circulation (Figure 1).

\subsection{Stocking and rearing of fish}

Following complete sanitization, a $750 \mathrm{~L}$ plastic water tank $\left(90 \times 51 \mathrm{~cm}^{2}\right)$ was used to stock fish. Bottom of the tank was filled with some cleaned brick lets that provided the fish feel like natural habitat. The tank was fitted with inlet-outlet pipes and two aerators for proper circulation as well as aeration of the tank water. After disinfection with potassium permanganate $(2 \mathrm{mg} / \mathrm{l}$ for $4-5$ hours) and acclimatization with tank water, locally collected healthy fifty tilapia (Oreochromis niloticus) and twenty magur (Clarias batrachus) fingerlings were stocked in the tank. The feed was supplied to the fish twice daily, in the morning at $9.00 \mathrm{am}$ and afternoon at $5.00 \mathrm{pm}$ initially at the rate of $10 \%$ magur fish body weight and $5 \%$ tilapia fish body weight during the first month and then the rate reduced to 5\% and 3\% for magur and tilapia respectively. Floating feed was used for feeding tilapia and sinking feed for magur.

\subsection{Bed preparation for lettuce culture}

Locally available six plastic containers $\left(44 \times 26 \times 24 \mathrm{~cm}^{3}\right)$ with upper side cut were used for lettuce culture as growbeds. Three containers used for aquaponics $\left(\mathrm{T}_{1}\right)$ where brick lets were used as bedding materials. The rest three containers, for traditional culture, were filled with crushed soil $\left(\mathrm{T}_{2}\right)$ each mixed with $300 \mathrm{~g}$ lime, $250 \mathrm{~g}$ flour, 250g mustard oil cake, and 50gm each of molasses, urea, TSP and potash. The aquaponics $\left(\mathrm{T}_{1}\right)$ growbeds were connected each with the fish holding tanks through PVC pipes to facilitate recirculation. After preparing grow beds, four healthy lettuce saplings were planted in four vertices of each container counting twenty four saplings in total in six different containers. Initially height of plant, leaf number of each plant, height of leaf and width of leaf were recorded. Fish tank waste water was used for watering plants in aquaponic system $\left(T_{1}\right)$ through a porous PVC pipe all the day except night whereas tap water was used for traditional soil beds $\left(\mathrm{T}_{2}\right)$. As no fertilizer was used in the aquaponic growbeds $\left(\mathrm{T}_{1}\right)$, plants' growth was slow for initial 10-15 days and then started at full swing with the growth of nitrifying bacteria.

\subsection{Collection of data}

Sampling was done fortnightly for the fish, plants, tank water and soil. For fish, sampling was done using scoop net. Ten tilapia and five magur were used to catch randomly for measuring length and weight by using an electronic compact balance (KD-S/F-en) and a cm scale during each sampling and then put back to the tank. 
Growth perameters of the fish was measured in terms of mean length and weight gain, feed conversion ratio (FCR), production and survival rate following standard mathematical procedures.

In order to assess the lettuce production performance in both the systems height of individual plant, leaf length and width, leaf area and number were measured fortnightly using an electronic compact balance (KD-S/F-en), a $\mathrm{cm}$ scale and an automatic digital electronic portable leaf area meter (Model LI-3100, Lincoln, NE-68504, USA). At the time of final harvest, the leaves and root weight and the total biomass content of lettuce were recorded.

During each sampling, water quality parameters such as Dissolved oxygen (DO), temperature and $\mathrm{pH}$ of inlet (from fish tank to aquaponics growbeds) and outlet (from aquaponics growbeds to fish tank) water were measured with the aid of "hanna instruments water quality testing kits". The chemical parameters of water and soil such as nitrite, nitrate, iron, phosphate, available phosphorus (P) and sulphur (S), exchangeable potassium $(\mathrm{K})$ and sodium $(\mathrm{Na})$ contents were measured with standard laboratory analysis procedure followed by Salam $e t$ al., 2014a.

\subsection{Data analysis}

Collected data were recorded in a notebook and then loaded in the computer for statistical analysis. One way ANOVA and Duncan's New Multiple Range Test (Duncan, 1955) were employed to test the significance of variation between the treatment means. All statistical analyses were carried out by MS Excel 2007 version and Excel-Stat software. The results have been presented in tabular and graphical forms.

\section{Results and Discussion}

\subsection{Water and soil quality parameters}

The water quality parameters of the fish tank remained within the suitable range for aquaculture. As observed, the mean $\mathrm{pH}$ value in fish tank water was $7.58 \pm 0.21$ that was within the acceptance level of both tilapia and magur (Swingle, 1968; Chervinski, 1982; Tanusri, 2013). In aquaponic system, nitrifying bacteria require $\mathrm{pH}$ within 7.2 to 8.2 , whereas nitrification is subdued below the $\mathrm{pH}$ value of 5 (Villaverde et al., 1997). The reported mean dissolved oxygen content (DO) in the tank water over the study period was $4.3 \pm 1.2 \mathrm{ppm}$ suggesting slightly lower value than ideal condition (DoF, 1996), although within the tolerance range of tilapia and magur (Balarin et al., 1986; Islam et al., 1986). The nitrifying bacteria (Nitrosomonas and Nitrobacter) resided on the root systems of aquaponic plants could have contributed to oxygen depletion through water recirculation (Sutton et al., 2006). As the present experiment was conducted in the winter season (December to March) the average temperature was slightly lower that varied from $17^{\circ}$ to $23.5^{\circ} \mathrm{C}$. Nevertheless, this temperature was quite suitable for fish culture as magur grow well within this range (Tanushri 2013) and the lethal temperature threshold for tilapia is below $11^{\circ} \mathrm{C}$ and above $42^{\circ} \mathrm{C}$ (Balarin et al., 1986). Moreover, temperature range of 7 to $35^{\circ} \mathrm{C}$ is needed to keep the nitrifying bacteria active in aquaponic system that was avail during the study period (Wortman and Wheaton, 1991).

The results of laboratory analysis of inlet water (waste water from tank to growbeds) and outlet water (recycled water from growbeds to tank) showed that the overall mineral contents of the outlet water were lower than that of inlet water that admit the findings of Salam et al., 2014b. The result implies that the minerals in the form of iron, phosphorus and nitrogen were high in fish tank waste water (Table 1). When this water was re-circulated through aquaponics growbeds, the nitrifying bacteria acted to convert the non edible form into consumable nutrients like nitrates for the lettuce plants. Thus the process renders the system hazard free.

Similar to the findings of Salam et al., 2014a, the biochemical analysis of aquaponic tank water in $\mathrm{T}_{1}$ and growing soil media in $\mathrm{T}_{2}$ revealed that the soil growbeds were much nutrient dense compared to aquaponic growbeds hence favorable for better production (Table 2).

\subsection{Fish Growth and production}

In this experiment, 50 tilapia and 20 magur fry were stocked in a plastic water tank (750 liter) and reared for 105 days. Because of its hardy, high yielding and omnivorous nature tilapia has become a common candidate in aquaponic system (Childress, 2003). The initial mean length and weight of the experimental tilapia were 13.74 $( \pm 1.77) \mathrm{cm}$ and $51.13( \pm 22.27) \mathrm{g}$ respectively that were increased to $16.69( \pm 2.60) \mathrm{cm}$ and $125.04( \pm 38.22) \mathrm{g}$ at the final harvest having the length and weight gain of $2.95( \pm .83) \mathrm{cm}$ and $73.91( \pm 15.95) \mathrm{g}$ respectively. Watanabe et al., 2004 and Licamele, 2009; of the University of Arizona reported that mean weight gain of tilapia was $85.39( \pm 12.04) \mathrm{g}$ after 180 days of rearing. Therefore, weight gain of tilapia was quite satisfactory in this study that might be due to better management practice, good quality feed and suitable temperature over the period. The FCR value of tilapia was 2.54 that is better than the reported FCR value (2.67) for tilapia in 
aquaponic system of Salam et al., 2014b. Here, survival rate of tilapia was $96 \%$ that outweighed the findings of Salam et al., 2013 who recorded 93\% survival rate. At the end of the experiment, total production of tilapia was $3.55 \mathrm{~kg}$ in $750 \mathrm{~L}$ tank which would be 47.30 tons/ha/105 days that surpassed the findings of Rana et al., 2015; who obtained tilapia production of 28 tons per hectare for 90 days rearing in ponds. The present finding is comparatively higher than the conventional semi intensive system.

To utilize the bottom space of the fish tank magur fry was released because of its high stocking density tolerance. The initial mean length of magur was $8.43( \pm 0.71) \mathrm{cm}$ and the final mean length was $15.63( \pm 1.08) \mathrm{cm}$ with the length gain of $7.2( \pm .37) \mathrm{cm}$ at final harvest. Hasan, 2014; reported that mean length gain of magur at the harvesting time were $17.80( \pm 0.09), 13.50( \pm 0.05)$ and $12.37( \pm 0.02) \mathrm{cm} \mathrm{in}_{1}, \mathrm{~T}_{2}$ and $\mathrm{T}_{3}$ respectively which were slightly higher than the present finding. The mean weight gain of magur in this study was $19.64( \pm 3.39) \mathrm{g}$ while the initial and final mean weight of fish were 3.78( \pm 1.00$) \mathrm{g}$ and $23.42( \pm 4.39) \mathrm{g}$ respectively that also conforms with the findings of Hasan, 2014. In the present study, the observed FCR value of magur was 2.84. Tarnchalanukit et al., 1983; estimated the FCR value of $C$. batrachus 1.24-1.32 in circular tank receiving high quality feed whereas Azimuddin et al., 1998; reported FCR from 1.73 to 2.04 for magur fed formulated feed. Thoses were little bit lower than the value of present experiment that might because tilapia and magur were combined cultured in the tank, hence tilapia consumed magur feed so FCR of magur was little bit high. The observed survival rate of magur was $80 \%$ that complies with Tarnchalanukit et al., 1983; who reported $79.53 \%$ survival rate of $C$. batrachus. In winter season, $0.314 \mathrm{~kg}$ of magur was obtained from $0.75 \mathrm{~m}^{2}$ area using plastic drum. If we convert the area in hectare then the total production of fish would be $4190 \mathrm{~kg} / \mathrm{ha} / 105$ days. The present finding was comparatively higher to the finding of Tanushri, 2013 who recorded the production of 382.11 and $222.07 \mathrm{~kg} / \mathrm{ha} / 113$ days respectively. Indeed tilapia and magur performed well in the system (Table 3, Figure $2 \& 3)$.

Table 1. Mineral contents of inlet and outlet water on different sampling dates.

\begin{tabular}{lllllllll}
\hline & \multicolumn{3}{c}{ Inlet water } & \multicolumn{3}{c}{ Outlet water } \\
\hline $\begin{array}{l}\text { Sampling } \\
\text { Date }\end{array}$ & $\begin{array}{l}\mathbf{F e} \\
(\mathbf{p p m})\end{array}$ & $\begin{array}{l}\mathbf{P O}_{\mathbf{4}} \\
(\mathbf{p p m})\end{array}$ & $\begin{array}{l}\mathbf{N O}_{\mathbf{2}} \\
(\mathbf{p p m})\end{array}$ & $\begin{array}{l}\mathbf{N O}_{\mathbf{3}} \\
(\mathbf{p p m})\end{array}$ & $\begin{array}{l}\mathbf{F e} \\
(\mathbf{p p m})\end{array}$ & $\begin{array}{l}\mathbf{P O}_{\mathbf{4}} \\
(\mathbf{p p m})\end{array}$ & $\begin{array}{l}\mathbf{N O}_{\mathbf{2}} \\
(\mathbf{p p m})\end{array}$ & $\begin{array}{l}\mathbf{N O}_{3} \\
(\mathbf{p p m})\end{array}$ \\
\hline $9 / 12 / 2014$ & 0.08 & 2.28 & 7.65 & 0.33 & 0.05 & 1.95 & 4.41 & 0.20 \\
$27 / 12 / 2014$ & 0.06 & 2.16 & 7.55 & 0.34 & 0.04 & 1.85 & 4.31 & 0.10 \\
$10 / 1 / 2015$ & 0.04 & 2.40 & 7.75 & 0.32 & 0.06 & 2.05 & 4.51 & 0.30 \\
$28 / 01 / 2015$ & 0.07 & 2.28 & 7.65 & 0.33 & 0.05 & 1.95 & 6.00 & 0.10 \\
$16 / 02 / 2015$ & 0.02 & 2.40 & 7.60 & 0.34 & 0.06 & 1.90 & 3.00 & 0.20 \\
$6 / 3 / 2015$ & 0.05 & 4.00 & 5.00 & 0.30 & 0.07 & 4.00 & 12.00 & 0.50 \\
Mean & 0.05 & 2.59 & 7.20 & 0.33 & 0.06 & 2.28 & 5.71 & 0.23 \\
& $( \pm 0.02)$ & $( \pm 0.70)$ & $( \pm 1.08)$ & $( \pm 0.2)$ & $( \pm 0.01)$ & $( \pm 0.84)$ & $( \pm 3.23)$ & $( \pm 0.15)$ \\
Significant & NS* & NS* & NS* & NS* & NS* & NS* & NS* & NS* \\
\hline
\end{tabular}

*Non significant when $\mathrm{P}<0.05$

Table 2. Mineral contents of aquaponics water and soil of traditional growbeds.

\begin{tabular}{lllll}
\hline Treatments & $\mathbf{P}(\mathbf{p p m})$ & $\mathbf{K}(\mathbf{p p m})$ & $\mathbf{S}(\mathbf{p p m})$ & $\mathbf{N a}(\mathbf{p p m})$ \\
\hline $\mathrm{T}_{1}$ (Aquaponics) & $2.25( \pm 0.63)$ & $7.35( \pm 0.75)$ & $2.82( \pm 0.39)$ & $22.17( \pm 1.23)$ \\
$\mathrm{T}_{2}$ (Soil) & $23.79( \pm 2.76)$ & $118.64( \pm 3.38)$ & $51.38( \pm 2.52)$ & $231.65( \pm 3.29)$ \\
\hline
\end{tabular}

Table 3. Comparative growth performance of tilapia and magur.

\begin{tabular}{lll}
\hline Growth Parameter & Tilapia & Magur \\
\hline Mean Initial Length $(\mathrm{cm})$ & $13.74( \pm 1.77)$ & $8.43( \pm 0.71)$ \\
Mean Final Length $(\mathrm{cm})$ & $16.69( \pm 2.60)$ & $15.63( \pm 1.08)$ \\
Mean Length Gain $(\mathrm{cm})$ & $2.95( \pm .83)$ & $7.2( \pm .37)$ \\
Percent Length Gain $(\%)$ & 21.47 & 85.00 \\
Mean Initial Weight $(\mathrm{g})$ & $51.13( \pm 22.27)$ & $3.78( \pm 1.00)$ \\
Mean Final Weight $(\mathrm{g})$ & $125.04( \pm 38.22)$ & $23.42( \pm 4.39)$ \\
Mean Weight Gain $(\mathrm{g})$ & $73.91( \pm 15.95)$ & $19.64( \pm 3.39)$ \\
Percent Weight Gain $(\%)$ & 144.55 & 519.00 \\
Survival Rate $(\%)$ & 96.00 & 80.00 \\
FCR & 2.54 & 2.84 \\
Production (tons/ha/105days) & 47.33 & 4.19 \\
\hline
\end{tabular}


Asian J. Med. Biol. Res. 2018, 4 (2)

Table 4. Production performance of lettuce in Aquaponics $\left(T_{1}\right)$ and traditional soil $\left(T_{2}\right)$.

\begin{tabular}{lllllllllllll}
\hline \multicolumn{3}{c}{ Plant height $(\mathrm{cm})$} & \multicolumn{3}{c}{ Leaf length $(\mathrm{cm})$} & \multicolumn{3}{c}{ Leaf area $\left(\mathrm{cm}^{2}\right)$} & \multicolumn{3}{c}{ Leaf number } & \multicolumn{2}{c}{ Leaf weight $(\mathrm{g})$} \\
\hline $\begin{array}{l}\text { Sampling } \\
\text { Date }\end{array}$ & $\mathrm{T}_{1}$ & $\mathrm{~T}_{2}$ & $\mathrm{~T}_{1}$ & $\mathrm{~T}_{2}$ & $\mathrm{~T}_{1}$ & $\mathrm{~T}_{2}$ & $\mathrm{~T}_{1}$ & $\mathrm{~T}_{2}$ & $\mathrm{~T}_{1}$ & $\mathrm{~T}_{2}$ \\
\hline $10 / 12 / 2014$ & 5.13 & 5.17 & 5.07 & 5.07 & 11.88 & 12.97 & 3.08 & 3.08 & - & - \\
& $( \pm 0.64) \mathrm{f}$ & $( \pm 0.8) \mathrm{f}$ & $( \pm 0.7) \mathrm{e}$ & $( \pm 0.74) \mathrm{c}$ & $( \pm 3.3) \mathrm{f}$ & $( \pm 4.1) \mathrm{d}$ & $( \pm 0.5) \mathrm{d}$ & $( \pm 0.5) \mathrm{d}$ & \\
$09 / 01 / 2015$ & 23.61 & 27.14 & 15.02 & 17.64 & 66.67 & 119.05 & 5.5 & 6.66 & 1.14 & 2.19 \\
& $( \pm 1.84) \mathrm{e}$ & $( \pm 2.78) \mathrm{e}$ & $( \pm 1.7) \mathrm{d}$ & $( \pm 2.13) \mathrm{b}$ & $( \pm 12.2) \mathrm{e}$ & $( \pm 51.9) \mathrm{c}$ & $( \pm 1.0) \mathrm{d}$ & $( \pm 1.0) \mathrm{cd}$ & $( \pm 0.30) \mathrm{c}$ & $( \pm 1.3) \mathrm{d}$ \\
$25 / 01 / 2015$ & 38.37 & 38.38 & 17.33 & 20 & 85.82 & 134.96 & 10 & 11.17 & 1.30 & 2.75 & $( \pm 0) \mathrm{c}$ \\
& $( \pm 3.63) \mathrm{d}$ & $( \pm 2.28) \mathrm{d}$ & $( \pm 1.5) \mathrm{c}$ & $( \pm 2.59) \mathrm{ab}$ & $( \pm 19.0) \mathrm{d}$ & $( \pm 47.9) \mathrm{bc}$ & $( \pm 2.3) \mathrm{c}$ & $( \pm 2.3) \mathrm{bc}$ & $( \pm 0.40) \mathrm{c}$ & $( \pm 1.7) \mathrm{cd}$ \\
$09 / 02 / 2015$ & 60.33 & 50.81 & 19.5 & 20.4 & 103.44 & 152.19 & 13.92 & 14.67 & 2.39 & 4.13 \\
& $( \pm 9.26) \mathrm{c}$ & $( \pm 6.11) \mathrm{c}$ & $( \pm 1.2) \mathrm{b}$ & $( \pm 2.46) \mathrm{a}$ & $( \pm 13.2) \mathrm{c}$ & $( \pm 21.9) \mathrm{bc}$ & $( \pm 4.1) \mathrm{bc}$ & $( \pm 3.9) \mathrm{b}$ & $( \pm 0.60) \mathrm{b}$ & $( \pm 1.9) \mathrm{c}$ \\
$24 / 02 / 2015$ & 77.33 & 63.38 & 21.19 & 22.43 & 163.02 & 166.18 & 17.58 & 21.5 & 5.97 & 5.64 \\
& $( \pm 15.43) \mathrm{b}$ & $( \pm 10.06) \mathrm{b}$ & $( \pm 1.8) \mathrm{a}$ & $( \pm 3.78) \mathrm{a}$ & $( \pm 39.7) \mathrm{b}$ & $( \pm 23.6) \mathrm{b}$ & $( \pm 7.1) \mathrm{ab}$ & $( \pm 9.7) \mathrm{a}$ & $( \pm 1.4) \mathrm{a}$ & $( \pm 1.6) \mathrm{b}$ \\
$01 / 03 / 2015$ & 89.83 & 72.75 & 22.1 & 22.05 & 195.82 & 215.23 & 20.92 & 25.08 & 6.49 & 7.14 \\
& $( \pm 18.27) \mathrm{a}$ & $( \pm 12.33) \mathrm{a}$ & $( \pm 2.0) \mathrm{a}$ & $( \pm 5.06) \mathrm{a}$ & $( \pm 46.6) \mathrm{a}$ & $( \pm 30.0) \mathrm{a}$ & $( \pm 8.4) \mathrm{a}$ & $( \pm 11.1) \mathrm{a}$ & $( \pm 1.9) \mathrm{a}$ & $( \pm 2.0) \mathrm{a}$ \\
\hline
\end{tabular}

Values in a row having similar letter (s) or without letters do not differ significantly whereas values bearing the dissimilar letter (s) differ significantly ( $\mathrm{p}<0.05)$ as per Duncan Multiple Range Test (DMRT)

Table 5. Lettuce root length, weight and total production at final harvest.

\begin{tabular}{llll}
\hline Treatments & Root length $(\mathbf{c m})$ & Root weight $(\mathbf{g})$ & Lettuce production (tons/ha/89days) \\
\hline $\mathrm{T}_{1}$ & 13.63 & 14.37 & 107.89 \\
$\mathrm{~T}_{2}$ & 12.15 & 12.86 & 123.25 \\
\hline
\end{tabular}

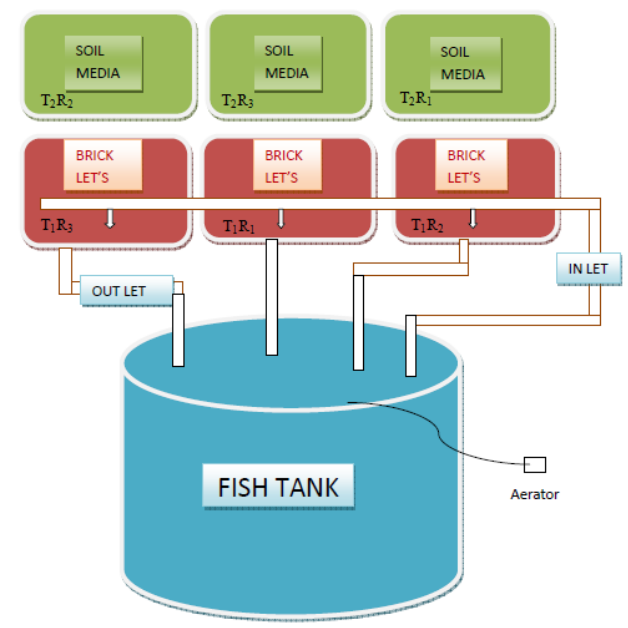

Figure 1. Layout of the experiment.

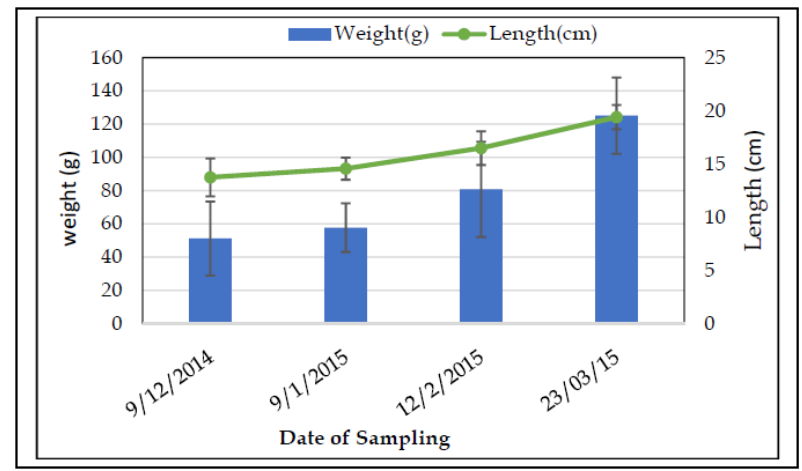

Figure 2. Length (cm) and weight (g) of tilapia on various sampling dates. 


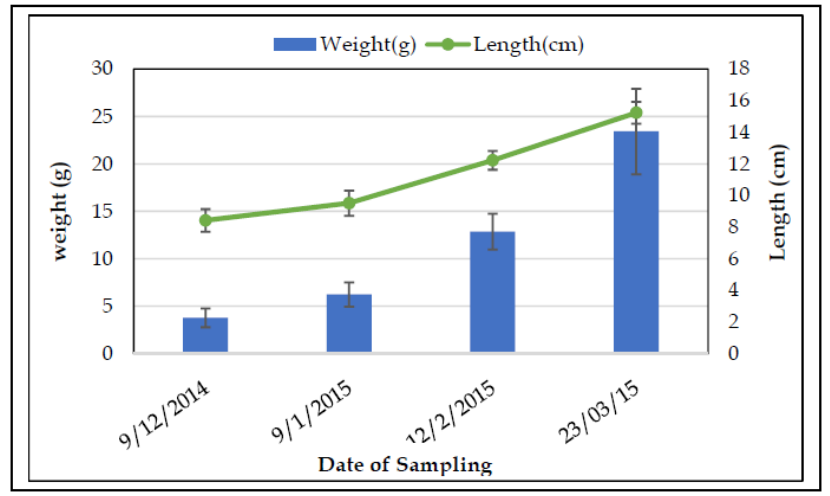

Figure 3. Length (cm) and weight $(\mathrm{g})$ of magur on various sampling dates.

\subsection{Lettuce growth and production}

During the study, the growth and production performances of lettuce in two treatments $\mathrm{T}_{1}$ (Aquaponics) and $\mathrm{T}_{2}$ (Soil) were recorded. The highest mean plant height was $89.83( \pm 18.27) \mathrm{cm}$ in $\mathrm{T}_{1}$ and $72.75( \pm 12.33) \mathrm{cm}$ in $\mathrm{T}_{2}$ although the differences in plant height among the two treatments on each sampling were insignificant $(\mathrm{P}<0.05)$. Mader, 2012; found the average height of lettuce were $7.34 \mathrm{~cm}$ in the soil, $6.52 \mathrm{~cm}$ in the gravel, and $5.7 \mathrm{~cm}$ in the which was comparatively lower than the present findings. Interestingly there was no significant difference among the observed data for final average leaf length and leaf area in two different treatments but $T_{2}$ performed slightly better than T1 (Table 4). The highest mean leaf number was $25.08( \pm 11.1)$ and it was found in $\mathrm{T}_{2}$. At that time mean leaf number in $\mathrm{T} 1$ was $20.92( \pm 8.49)$ that was not significantly different $(\mathrm{P}<0.05)$. The highest mean leaf weight in $\mathrm{T}_{2}$ was 7.14( \pm 2.0$) \mathrm{g}$ whereas in $\mathrm{T}_{1}$ was $6.49( \pm 1.9) \mathrm{g}$. Previous study of Mader, 2012 also reported different leaf weights for different growbeds such as $2.07 \mathrm{~g}$ in soil, $1.52 \mathrm{~g}$ in gravel, and $0.84 \mathrm{~g}$ in fiber. Because of having adequate space in brick-lets growbed, aquaponic lettuce $\left(\mathrm{T}_{1}\right)$ attained the highest root length of $13.63 \mathrm{~cm}$ than in soil $\left(\mathrm{T}_{2}\right)$ counted $12.15 \mathrm{~cm}$ (Table 5). This finding also follows the pattern of Mader, 2012 . After the final harvest, the highest estimated lettuce production of $1410.76 \mathrm{~g}(1410.76 \mathrm{~g} / 0.114 \mathrm{~m} 2 / 89$ days or 123.25 tons $/ \mathrm{ha} / 89$ days) was obtained from $\mathrm{T}_{2}$ whereas $\mathrm{T}_{1}$ produced $1234.23 \mathrm{~g}\left(1234.23 \mathrm{~g} / 0.114 \mathrm{~m}^{2} / 89\right.$ days or 107.89 tons/ha/ 89 days) of lettuce although the difference was statistically insignificant $(\mathrm{P}<0.05)$. However, in this study traditional soil preformed better that is similar to the previous study (Mader, 2012). In contrast, Salam et al., 2014a; concluded differently where aquaponics performed better than soil and hydroponics respectively. In this experiment maximum mineral contents, essential for plant growth, were found in traditional soil media $\left(\mathrm{T}_{2}\right)$ that might has outweighed the synergistic effect of aquaponics $\left(\mathrm{T}_{1}\right)$ in lettuce production (Rakocy et al., 2004).

\section{Conclusions}

Food safety in public health is a burning issue now-a-days all over the world including Bangladesh. Aquaponics has already proved its potentiality in providing hazard free healthy fish and vegetables. Comparison of the traditional farming with aquaponics may lead to greater adoption of the aquaponics system in public and private sectors. Although the production of lettuce was not greater than the traditional farming in soil but the products of aquaponics were fully free of fertilizers, insecticides and other hazardous chemicals that are conventionally being used in traditional farming. Thus the benefit of having organically produced safe food from aquaponics can easily outweigh the production benefit of traditional farming. However, further studies are needed to justify more clearly the superiority of the aquaponic system the traditional one.

\section{Conflict of interest}

None to declare.

\section{References}

Azimuddin KM, 1998. Effect on stocking density on the growth of Thai pangus, Pangasius sutchi (Folwer) in net cage by using formulated diet, MS Thesis, Department of Aquaculture, Bangladesh Agricultural University, Mymensingh. pp.1- 62.

Balarin JD, R Horrer and ATC Armitage, 1986. Research on intensive culture of tilapia in tanks. In Proceedings, African Seminar in Aquaculture. Pudoc, Wageningen. pp. 206-216. 
Bethe LA, MA Salam, UK Fatema and KMS Rana, 2017. Effect of Foliar Spray of compost tea on water spinach (Ipomoea aquatica) in aquaponic system. Int. J. Fish. Aquat. Stud., 5: 203-207.

Chervinski J, 1982. Environmental physiology of tilapias. In RSV Pullin and LM Connel (editors.). The biology of tilapias, ICLARM. Conference proceedings, Manila, Philippines. 7. pp. 119-128.

Childress VW, 2003. Promising Alternatives in Agri-technology: Aquaponics. Resources in Technology, Copyright 2002 EBSCO Publishing, Dec.-Jan. 2003.

DoF (Department of Fisheries), 1996. Technologies and Management for Fisheries Development. pp: 21-148.

Duncan DB, 1955. Multiple range and multiple F tests. Biometrics 11:1-42.

Geoff W, 2002. Greenhouse aquaponics proves to be superior to indoor hydroponics. Aquaponics J., 1: 08-13.

Harmon T, 2001. A look at filtration in aquaponic system: bead filters. Aquaponics J., 5: 16-19.

Hasan MZ, 2014. Growth and Production Performance of Vietnamese Koi (Anabas testudineus) with Magur (Clariasbatrachus) at Different Stocking Densities in a Farming Ponds, MS Thesis, Department of Aquaculture, Bangladesh Agricultural University, Mymensingh. pp. 1-32.

Haug RT and McCarty PL, 1972. Nitrification with submerged filters. J. Water Pollut. Control Fed., 44: 20-86.

Islam MA, AKMN Islam and SM Rahmatullah, 1986. The influence of stimulant size and stock of fishes on the success of induced breeding of magur (Clarias batrachus L.). Bangladesh J. Aquacult., 8: 21-23.

Islam MK, KMS Rana, R Afrin, S Zahan and MA Salam, 2018. Efficacy of wish pond-aquaponics system in mitigating water pollution and safe food production. J. Entom. Zool. Stud., 6: 405-410.

Licamele JD, 2009. Biomass Production and Nutrient Dynamics in an Aquaponics System.Department Of Agriculture and Biosystems engineering. The University Of Arizona, USA. pp. 1-68.

Mader J, 2012. Plant Growth in Aquaponics System through Comparison of Different Plant Media. Westover Honors Program. Mader thesis. pp. 1-99.

McMurtry MR, DC Sanders, JD Cure, RG Hodson, BC Haning and PC St Amand, 1997. Efficiency of water use of an integrated fish/vegetable co-culture system. J. World Aquacult. Soc., 28: 420-428.

Normala W, E Abentin, YSK Annita, S. Shigeharu and M. Saleem, 2010. Producing organic fish and mint in an Aquaponic system. Aquaponics J., 58: 28-33.

Rakocy JE, DS Bailey, KA Shultz and WM Cole, 1997. Evaluation of a commercial-scale aquaponic unit for the production of Tilapia and lettuce. In: Tilapia aquaculture: proceedings from the 4th international symposium on Tilapia in Aquaculture. Northeast Regional Agricultural Engineering Service, Ithaca, New York, pp. 603613.

Rakocy JE, DS Bailey, RC Shultz and ES Thoman, 2004. Update on tilapia and vegetable production in the UVI aquaponics system. New Dimensions on Farmed Tilapia: Proceedings of the Sixth International Symposium on Tilapia in Aquaculture, Manila, Philippines. pp. 676-690.

Rana KMS, MA Salam, S Hashem and MA Islam, 2015. Development of Black Soldier Fly Larvae Production Technique as an Alternate Fish Feed. Int. J. Res. Fish. Aquacult., 5: 41-47.

Salam MA, M Asadujjaman and MS Rahman, 2013. Aquaponic for improving high density fish pond water quality through raft and rack vegetable production. World J. Fish and Marine Sci., 53: 251-256.

Salam MA, MY Prodhan, SM Sayem and MA Islam, 2014a. Comparative growth performances of taro plant in aquaponics vs other systems. Int. J. Innov. Appl. Stud., 7: 941-946.

Salam MA, N Jahan, S Hashem and KMS Rana, 2014b. Feasibility of Tomato Production in Aquaponic System in Summer using Different Media. Prog. Agricult., 25: 54-62.

Sutton JC, CR Sopher, TN Owen-Going, W Liu, B Grodzinski, JC Hall and RL Benchimol, 2006. Etiology and epidemiology of Pythum root rot in hydroponic crops: Current knowledge and Perspectives. J. Sum. Phytopathologica, 32: 307-321.

Swingle HS, 1968. Fish kills caused by phytoplankton blooms and their prevention. FAO. Fish Reproduction, 4: 407-411.

Tanushri DN, 2013. Rearing of Magur Fry (C. batrachus) Using Formulated Feed with Wheat Grass Powder in Plastic Half Drum, MS Thesis, Department of Aquaculture, Bangladesh Agricultural University, Mymensingh. pp. 1-47.

Tarnchalanukit W, Chuapoehuk W and Suraniranat P, 1983. Pal duck Dan culture in circular concrete ponds with water recalculating system, PhD Thesis, Department of Aquaculture, Faculty of Fisheries, Kasetsart University, Bangkok, Thailand. pp. 1-176.

Timmons MB, JM Ebeling, FW wheaton, ST Summerfelt and BJ Vinci, 2002. Recirculating aquaculture systems, $2^{\text {nd }}$ Edition. Northeast Reg. Aquaculture Center Publ. No. 01-002

Tyson RV, EH Simon, JM White and EM Lamb, 2004. Reconciling water quality parameters impacting nitrification in aquaponics: The pH levels. Proc. Fla. State Hort. Sco., 117: 79-83. 
Tyson RV, RC Hochmuth, EM Lamb, GJ Hochmuth and MS Sweat, 2001. A decade of change in Florida's greenhouse vegetable industry: 1991-2001. Proc. Fla. State. Hort. Soc., 114: 280-283.

Villaverde S, PA García-Encina and F Fdz-Polanco, 1997. Influence of $\mathrm{pH}$ over nitrifying biofilm activity in submerged biofilters. Water Res., 31(5): 1180-1186.

Watanabe WO, TM Losordo, K Fitzsimmons and F Hanley, 2004. Tilapia production systems in the americas: technical advances, trends and challenges. Rev. Fish. Sci. 10: 465-498.

Waten BJ and RL Busch, 1984. Tropical production of Tilapia (Sarotherodon aurea) and tomatoes (Lycopersicon esculentum) in a small-scale recirculating water system. Aquaculture, 41: 271-283.

Wortman B and F Wheaton, 1991. Temperature effects on biodrum nitrification. J. Aquacult. Eng., 10: 183-205. 